\title{
PENGEMBANGAN METODE PENGUJIAN KEASLIAN BERAS ACEH MENGGUNAKAN NIRS DENGAN METODE PCA
}

(Development of Methods for Testing the Authenticity of Aceh Rice Using NIRS with the PCA Method)

\author{
Masyitah $^{1}$, Syahrul $^{1}$, Zulfahrizal $^{1 *}$ \\ Program Studi Teknik Pertanian, Fakultas Pertanian, Universitas Syiah Kuala \\ *Corresponding author: zulfahrizal@unsyiah.ac.id
}

\begin{abstract}
Abstrak.
Tujuan dari penelitian ini adalah membangun model pendugaan untuk menilai keaslian beras Aceh berdasarkan spektrum NIRS yang dihasilkan. Pendeteksian keaslian beras Aceh secara cepat dan efesien dapat diwujudkan melalui pengembangan teknologi Near Infrared Reflectance Spectroscopy (NIRS). Penelitian ini menggunakan beras varietas Sigupai (Aceh Barat Daya), varietas Sanbay (Simeulue) dan varietas Ciherang. Jumlah sampel yang digunakan pada penelitian ini adalah 45 sampel. Pengukuran spektrum beras menggunakan Self developed FT-IR IPTEK T-1516. Klasifikasi data spektrum beras menggunakan Principal Component Analysis (PCA) dengan dua pretreatment yaitu De-trending dan Multiplicative Scatter Correction. Hasil penelitian ini diperoleh yaitu: Spektrum NIRS beras menunjukkan keberadaan kandungan lemak pada panjang gelombang $2355 \mathrm{~nm}-2462 \mathrm{~nm}$. Kandungan karbohidrat pada panjang gelombang $2256 \mathrm{~nm}-2321 \mathrm{~nm}$. Kandungan protein pada panjang gelombang $2056 \mathrm{~nm}-2166 \mathrm{~nm}$. Kandungan kadar air pada panjang gelombang $1910 \mathrm{~nm}-1980$ $\mathrm{nm}$ dan panjag gelombang $1411 \mathrm{~nm}-1492 \mathrm{~nm}$ menunjukkan kandungan protein dan kadar air. NIRS dengan metode PCA mampu membedakan pencampuran beras Sigupai dengan beras Ciherang dimana pembedaan terbaik terjadi dalam bentuk dua macam pengelompokan yaitu beras Sigupai $\geq 75$ dan beras Sigupai $\leq 50$ dan pretreatment de-trending merupakan pretreatment terbaik dalam mengklasifikasi beras Aceh (Sigupai dan Sanbay) dengan beras Nasional (Ciherang).
\end{abstract}

Kata kunci : Varietas beras, NIRS, PCA, Pretreatment.

\begin{abstract}
.
The purpose of this study is to develop a prediction model to assess the authenticity of Aceh rice based on the NIRS spectrum produced. The detection of the authenticity of Aceh rice quickly and efficiently can be realized through technological development Near Infrared Reflectance Spectroscopy (NIRS). This study uses Sigupai rice varieties (Aceh Barat Daya), Sanbay (Simeulue) and Ciherang. The number of samples used in this study was 45 samples. Measurement of rice spectrum using Self developed FT-IR IPTEK T-1516. Rice spectrum data classification uses the Principal Component Analysis (PCA) with two pretreatments, namely De-trending and Multiplicative Scatter Correction. The results of this study were obtained: NIRS spectrum of rice showed the presence of fat content at a wavelength of $2355 \mathrm{~nm}-2462 \mathrm{~nm}$. Carbohydrate content at wavelength 2256 $\mathrm{nm}-2321 \mathrm{~nm}$. Protein content at wavelength $2056 \mathrm{~nm}-2166 \mathrm{~nm}$. The content of water content at a wavelength of $1910 \mathrm{~nm}-1980 \mathrm{~nm}$ and wave length of $1411 \mathrm{~nm}-1492 \mathrm{~nm}$ shows the protein content and water content. NIRS with the PCA method was able to distinguish the mixing of Sigupai rice from Ciherang rice where the best differentiation occurred in the form of two types of grouping namely Sigupai rice $\geq 75$ and Sigupai rice $\leq 50$ and de-trending pretreatment was the best pretreatment in classifying Aceh rice (Sigupai and Sanbay) with National rice (Ciherang).
\end{abstract}

Keywords: Rice varieties, NIRS, PCA, Pretreatment.

\section{PENDAHULUAN}

Aceh merupakan salah satu provinsi yang memiliki kekayaan plasma nutfah padi yang sangat banyak. Keberadaan varietas lokal padi Aceh sekarang dalam keadaan kritis, dan semakin sulit ditemukan di Aceh. Ratusan varietas padi lokal telah lenyap dari petani, sebagian diantaranya sudah tidak ditemukan lagi di Aceh. Penggunaan varietas unggul nasional (varietas hibrida) menyebabkan tergesernya varietas lokal. Jika ini berlangsung secara terus-menerus maka semakin lama varietas padi lokal akan punah. Hal ini merupakan suatu kerugian yang sangat besar atas hilangnya kekayaaan plasma nutfah padi lokal Aceh 
(Baktiar, 2009). Oleh karena itu, perlu dipelihara dan dilestarikan kembali untuk menjaga keaslian beras varietas lokal aceh.

Pendeteksian keaslian beras Aceh secara cepat dan efesien dapat diwujudkan melalui pengembangan teknologi Near Infrared Reflectance Spectroscopy (NIRS). NIRS telah menjadi salah satu metode non-destruktif yang paling menjanjikan yang dapat digunakan untuk analisis dalam berbagai bidang, termasuk di bidang pertanian. Melalui pengembangan ilmu komputer dan chemometric, kemampuan aplikasi teknik NIRS menjadi lebih populer dan menarik banyak perhatian para peneliti dalam bidang pangan. Komponen dengan presentase konsentrasi $0.1 \%$ dapat dideteksi dan dievaluasi menggunakan NIRS (Cen dan He 2007; Munawar 2014).

\section{METODE PENELITIAN}

\section{Tempat dan Waktu Penelitian}

Penelitian ini telah dilaksanakan pada bulan April sampai Juli 2018. Bertempat di Laboratorium Instrumentasi dan Energi, Program Studi Teknik Pertanian, Fakultas Pertanian, Universitas Syiah Kuala, Banda Aceh.

\section{Alat dan Bahan}

Alat yang digunakan pada penelitian ini adalah Self developed FT-IR IPTEK T1516, botol plastik, timbangan dan unscrambler software ${ }^{\circledR} X$ version 10.1 . Sedangkan bahan yang digunakan pada penelitian ini adalah Beras varietas Sigupai (Aceh Barat Daya) sebanyak 400g, varietas Sanbei (Simeulue) sebanyak $140 \mathrm{~g}$ dan varietas Ciherang $400 \mathrm{~g}$.

\section{Persiapan Bahan}

Masing-masing varietas ini terlebih dahulu dilakukan sortasi yang berfungsi untuk memisahkan beras utuh dan beras kepala dengan beras patah, menir, dan kotoran. Kemudian beras dari masing-masing varietas ini dilakukan pencampuran dengan enam perlakuan. Masing-masing perlakuan berjumlah 8 kali ulangan dan 7 kali ulangan untuk perlakuan beras Sigupai $100 \%$ (tanpa pencampuran), beras Ciherang100\% (tanpa pencampuran) dan beras Sanbay $100 \%$ (tanpa pencampuran). Sehingga total sampel yang digunakan pada penelitian ini adalah sebanyak 45 sampel. Perlakuan pencampuran beras dapat dilihat pada Tabel 1.

Tabel 1. Perlakuan Pencampuran Beras Aceh dengan Beras Nasional (Ciherang) per $20 \mathrm{~g}$

\begin{tabular}{crrrrrr}
\hline Jenis Beras & \multicolumn{7}{c}{ Persentase Berat $(\%)$} \\
\hline Ciherang & 100 & 75 & 50 & 25 & 0 & 0 \\
Sigupai & 0 & 25 & 50 & 75 & 100 & 0 \\
Sanbay & 0 & 0 & 0 & 0 & 0 & 100 \\
\hline
\end{tabular}

Selanjutnya beras yang telah dicampur dimasukkan ke dalam botol plastik yang berukuran kecil. Beras yang digunakan dalam satu sampel sebanyak $20 \mathrm{~g}$ pada masingmasing varietasnya. 


\section{Pengaturan Alat Spektrum}

Spektrum NIRS untuk beras didapatkan menggunakan Self developed FT-IR IPTEK T-1516. Menurut Zulfahrizal et al (2017) kalibrasi background/reference dilakukan tiap jam. Pengendalian kerja alat untuk pembuatan workflow dan menjalankan workflow menggunakan software thermo itegration ${ }^{\circledR}$ dan untuk running alat dilakukan oleh termo operation ${ }^{\circledR}$. Workflow dibuat untuk mengatur alat agar bekerja untuk mengakuisisi spektrum absorban, memindai sampel beberapa kali, lalu merata-ratakan hasilnya, dan menyimpan hasil pemindaian dalam tiga bentuk file yakni *.SPA, *.JDX dan *.CSV. Adapun selang gelombang yang digunakan antara $1000 \mathrm{~nm}-2500 \mathrm{~nm}$ dengan interval $0.4 \mathrm{~nm}$.

\section{Akuisisi Spektrum NIRS Bubuk Biji Kakao}

Akuisisi spektrum beras dilakukan dalam bentuk tumpukan. Masing-masing sampel yang telah dimasukkan ke dalam botol plastik akan dilakukan pengambilan spektrum dengan cara diletakkan masing-masing sampel tersebut pada sensor. Data absorban diperoleh dengan cara mentransformasikan nilai reflektan/pantulan ke dalam bentuk Log (1/R).

\section{Pemeriksaan Data Outlier PCA + Hotteling $\mathbf{T}^{2}$ Elipse}

Principal Component Analysis (PCA) untuk mengekplorasi kemiripan spektrum antar sampel dan untuk mencari outliers data dengan menggunakan metode Hotteling $T^{2}$ ellipse. Data yang berada diluar elips akan dideteksi sebagai data outliers dan selanjutnya dibuang (Zulfahrizal, 2016).

\section{Model Klasifikasi}

Klasifikasi keaslian beras Aceh dilakukan berdasarkan tipikal spektrum yang didapatkan. Keseluruhan data dipakai sebagai dataset yang digunakan untuk membangun model klasifikasi keaslian beras Aceh dengan metode koreksi yaitu De-Trending (DT) dan Multiplicative scatter correction (MSC). Model klasifikasi dibangun dengan menggunakan metode PCA.

\section{HASIL DAN PEMBAHASAN}

\section{Spektrum NIRS}

Akuisisi spektra beras dilakukan pada rentang panjang gelombang $4000-10.000$ $\mathrm{cm}^{-1}(1000 \mathrm{~nm}-2500 \mathrm{~nm})$. Pengambilan spektrum awal (raw) pada penelitian ini dilakukan pada dua perlakuan. Perlakuan pertama, pengambilan spektrum awal pada masing-masing varietas beras yaitu varietas Sigupai, Sanbay dan Ciherang. Perlakuan kedua, pengambilan spektrum awal pada beras campuran (beras Sigupai dengan Ciherang).

\section{Spektrum Awal Beras Tanpa Campuran}

Berdasarkan spektrum awal puncak gelombang penyerapan terlihat sebanyak 5 puncak. Puncak gelombang pertama terjadi pada panjang gelombang $4123 \mathrm{~cm}^{-1}-4308 \mathrm{~cm}^{-1}$ (2355 nm - $2425 \mathrm{~nm}$ ) menunjukkan keberadaan senyawa kandungan lemak. Panjang gelombang yang menunjukkan keberadaan kandungan lemak pada penelitian ini mendekati dengan hasil penelitian yang telah dilakukan oleh Klaithin (2012) bahwa kandungan lemak berada pada panjang gelombang $4329 \mathrm{~cm}^{-1}(2310 \mathrm{~nm})$. Puncak gelombang kedua terjadi pada panjang gelombang $4370 \mathrm{~cm}^{-1}-4432 \mathrm{~cm}^{-1}(2256 \mathrm{~nm}-2288 \mathrm{~nm})$ menunjukkan keberadaan senyawa kimia $\mathrm{C}-\mathrm{H}-\mathrm{O}$ dimana senyawa tersebut diduga sebagai kandungan karbohidrat. 
Sesuai dengan pernyataan Cen dan He (2007) terdapat ikatan kimia kandungan karbohidrat pada panjang gelombang tersebut.

Puncak gelombang ketiga terjadi pada panjang gelombang berkisaran $4617 \mathrm{~cm}^{-1}$ $4864 \mathrm{~cm}^{-1}(2055 \mathrm{~nm}-2165 \mathrm{~nm})$. Panjang gelombang tersebut menunjukkan keberadaan senyawa kimia C-O-N-H dimana senyawa tersebut diduga sebagai kandungan protein. Hal serupa juga dibuktikan pada penelitian yang telah dilakukan oleh Chen et al (2008) keberadaan kandungan protein terdapat pada panjang gelombang $4752 \mathrm{~cm}^{-1}(2104 \mathrm{~nm})$. Dan juga sesuai dengan pernyataan Firdaus (2014) bahwa keberadaan kandungan protein terdapat pada panjang gelombang $4739 \mathrm{~cm}^{-1}(2110 \mathrm{~nm})$.

Puncak gelombang keempat terjadi pada panjang gelombang $5049 \mathrm{~cm}^{-1}-5234 \mathrm{~cm}^{1}$ (1910 nm - $1980 \mathrm{~nm})$ menunjukkan keberadaan senyawa kimia $\mathrm{H}_{2} \mathrm{O}$ dimana senyawa tersebut diduga sebagai kandungan kadar air. Puncak gelombang kelima terjadi pada panjang gelombang berkisaran $6777 \mathrm{~cm}^{-1}-7085 \mathrm{~cm}^{-1}(1411 \mathrm{~nm}-1475 \mathrm{~nm})$. Panjang gelombang tersebut menunjukkan keberadaan senyawa kimia C-O-N-H dan $\mathrm{H}_{2} \mathrm{O}$ dimana senyawa tersebut diduga sebagai kandungan protein dan kadar air. Panjang gelombang yang menunjukkan keberadaan protein dan kadar air pada penelitian ini memiliki kemiripan dengan hasil penelitian Chen et al (2008) panjang gelombang $5170 \mathrm{~cm}^{-1}(1934 \mathrm{~nm})$ menunjukkan keberadaan kadar air dan panjang gelombang $6821 \mathrm{~cm}^{-1}(1466 \mathrm{~nm})$ berkaitan dengan kadar air dan protein. Hal ini juga sesuai dengan pernyataan Osborne at al (1993) terdapat kandungan kadar air pada panjang gelombang $5154 \mathrm{~cm}^{-1}(1940 \mathrm{~nm})$ dan $6896 \mathrm{~cm}^{-1}$ $(1450 \mathrm{~nm})$.

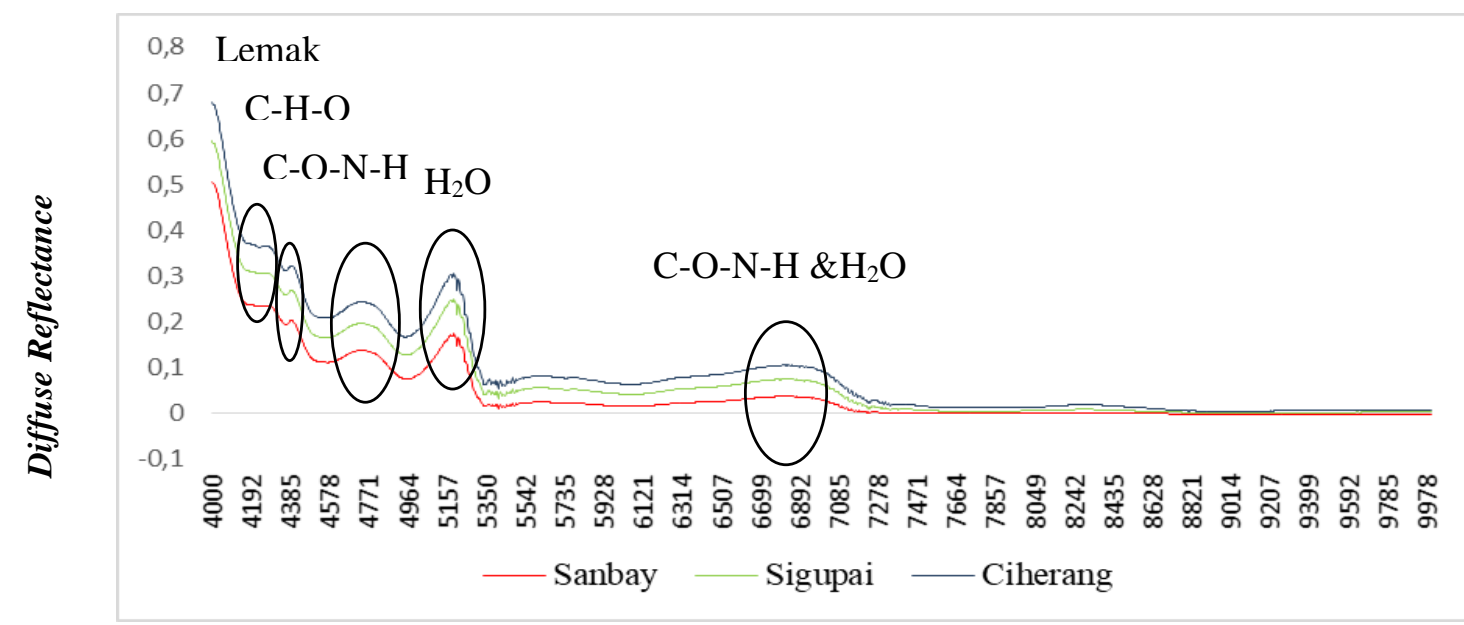

Panjang Gelombang $\left(\mathrm{cm}^{-1}\right)$

Gambar 1. Spektrum Awal Beras Tanpa Campuran dengan Satu Sampel

\section{Spektrum Awal Beras Campuran}

Spektrum awal pada pencampuran beras Sigupai dan beras Ciherang pada Gambar 2, dimana spektrum beras Sigupai $100 \%$ dan Sigupai75\% berada diantara spektrum beras Sigupai50\% dan Sigupai25\%. Spektrum beras Sigupai $50 \%$ berada pada posisi paling tinggi, sedangkan spektrum beras Sigupai $25 \%$ berada pada posisi paling rendah. Untuk spektrum pada masing-masing pencampuran beras tidak terlalu berbeda, sama halnya dengan spektrum awal pada beras tanpa campuran. Hal ini juga menunjukkan meskipun beras 
dicampurkan dengan varietas yang berbeda jika masing-masing varietas beras tersebut memiliki komposisi yang relatif sama, maka spektrum beras yang dihasilkan juga akan terlihat hampir sama.

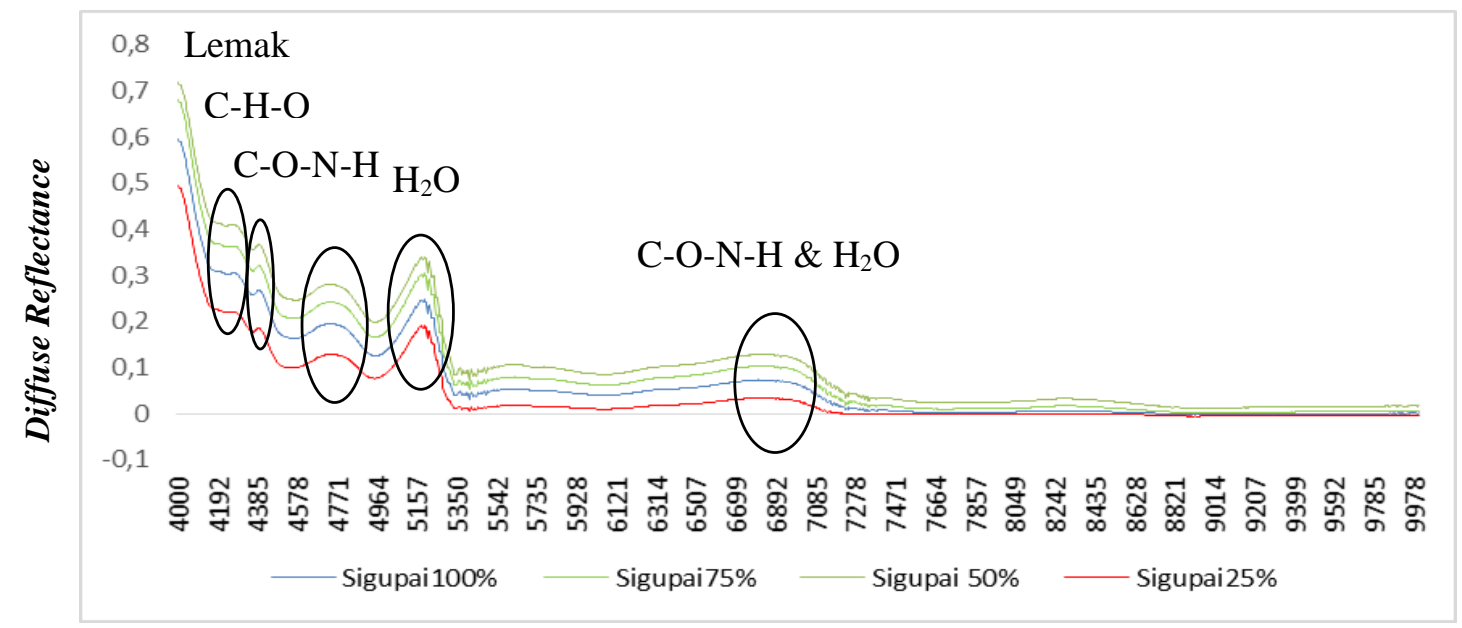

Panjang Gelombang $\left(\mathrm{cm}^{-1}\right)$

Gambar 2. Spektrum Awal Pencampuran Beras Sigupai dengan Ciherang Satu Sampel

\section{Outlier Removal}

Setelah dilakukan akusisi spektrum pada beras tanpa campuran dan beras campuran, langkah selanjutnya adalah mendeteksi keberadaan data pencilan dengan menggunakan metode PCA (Principal Component Analysis) yang dikombinasikan dengan Hotelling $T^{2}$ ellipse yang akan membuat data lebih sempurna. Setelah melakukan analisa, data yang berada diluar garis ellips tidak termasuk ke dalam data pencilan melainkan sebagai data pengungkit, sehingga data beras tanpa campuran dan beras campuran tidak ada yang perlu di remove.

\section{Klasifikasi Beras dengan Metode PCA (Principal Component Analsis) Beras Tanpa Campuran}

Klasifikasi metode ini dengan cara menggelompokkan data seperti pada Gambar 3 (a). Hasil analisis PCA tanpa pretreatment terlihat bahwa beras Aceh (Sigupai) dan beras Nasional (Ciherang) yang mana keduanya sangat berbeda dan terpisah. Perlakuan tanpa pretreatment pada beras tanpa pencampuran menghasilkan total data (PC1 dan $\mathrm{PC} 2)$ adalah sebesar 99\%. Data ini terklasifikasi secara baik dengan presentase keberhasilan sebesar 92,85\%. Yang mana beras Aceh (Sigupai) dan beras Nasional (Ciherang) masing-masing terklasifiksi sebesar $85,7 \%$ dan $100 \%$. Hal ini dikarenakan terdapat satu data varietas Sigupai yang berada diluar posisinya $(7,14 \%)$.

Selanjutnya untuk memperbaiki hasil klasifikasi beras Aceh (Sigupai) dengan beras Nasional (Ciherang) menggunakan metode PCA ditambahkan pretreatment yaitu MSC dan DT. Klasifikasi PCA dengan penambahan pretreatment MSC menghasilkan total (PC1 dan PC2) sebesar 93\%. Data ini terklasifikasi secara baik dengan presentase keberhasilan sebesar 85,7\%. Beras Aceh (Sigupai) dan beras Nasional (Ciherang) masing-masing terklasifikasi sebesar $85,7 \%$. Hal ini dikarenakan terdapat satu data pada masing-masing varietas yang berada diluar posisinya (14,3\%). Klasifikasi PCA beras Sigupai dan beras Ciherang dengan penambahan pretreament MSC dapat dilihat pada Gambar 3 (b). 
Klasifikasi PCA dengan penambahan pretreatment DT pada beras Aceh (Sigupai) dan beras Nasional (Ciherang) menghasilkan total (PC-1 dan PC-2) adalah sebesar 92\%. Data ini terklasifikasi secara baik dengan presentase keberhasilan sebesar 92,85\%. Yang mana beras Aceh (Sigupai) dan beras Nasional (Ciherang) masing-masing terklasifiksi sebesar $85,7 \%$ dan $100 \%$. Hal ini dikarenakan terdapat satu data varietas Sigupai yang berada diluar posisinya $(7,14 \%)$. Klasifikasi PCA beras Sigupai dan beras Ciherang dengan penambahan pretreatment DT dapat dilihat pada Gambar 3 (c).

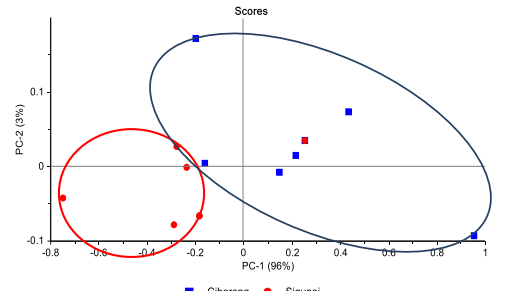

- cilerang - sigupa
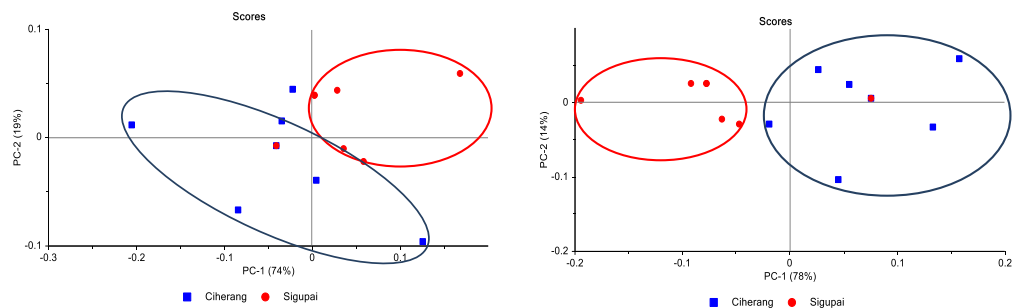

Gambar 3. Klasifikasi PCA (a) Tanpa Pretreatment (b) Pretreatment MSC dan (c) Pretreatment DT Beras Sigupai dan Ciherang

Klasifikasi beras Aceh (Sanbay) dan beras Nasional (Ciherang) tanpa pretreatment menggunakan metode PCA dapat membedakan dua jenis varietas tersebut dengan menghasilkan total (PC-1 dan PC-2) adalah sebesar 100\%. Data ini terklasifikasi cukup baik dengan presentase keberhasilan sebesar 85,7\%. Klasifikasi beras Aceh (Sanbay) dan beras Nasional (Ciherang) masing-masing terklasifikasi sebesar $71,4 \%$ dan $100 \%$. Hal ini dikarenakan terdapat dua data varietas Sigupai yang berada diluar posisinya (14,3\%). Klasifikasi PCA beras Sanbay dan beras Ciherang tanpa pretreatment dapat dilihat pada Gambar 4 (a).

Klasifikasi beras Aceh (Sanbay) dengan beras Nasional (Ciherang) menggunakan metode PCA dengan penambahan pretreatment MSC menghasilkan total (PC1 dan PC2) sebesar 98\%. Data ini terklasifikasi secara baik dengan presentase keberhasilan sebesar 85,7\%. Beras Aceh (Sanbay) dan beras Nasional (Ciherang) masing-masing terklasifikasi sebesar $85,7 \%$. Hal ini dikarenakan terdapat satu data masing-masing varietas yang berada diluar posisinya (14,3\%). Klasifikasi PCA beras Sanbay dan beras Ciherang dengan penambahan pretreament MSC dapat dilihat pada Gambar 4 (b).

Klasifikasi PCA dengan penambahan pretreatment DT pada beras Aceh (Sanbay) dan beras Nasional (Ciherang) menghasilkan total (PC-1 dan PC-2) adalah sebesar 95\%. Data ini terklasifikasi secara baik dengan presentase keberhasilan sebesar 92,85\%. Yang mana beras Aceh (Sanbay) dan beras Nasional (Ciherang) masing-masing terklasifiksi sebesar $85,7 \%$ dan $100 \%$. Hal ini dikarenakan terdapat satu data varietas Sigupai yang berada diluar posisinya $(7,14 \%)$. Klasifikasi PCA beras Sanbay dan beras Ciherang dengan penambahan pretreament DT dapat dilihat pada Gambar 4 (c). 


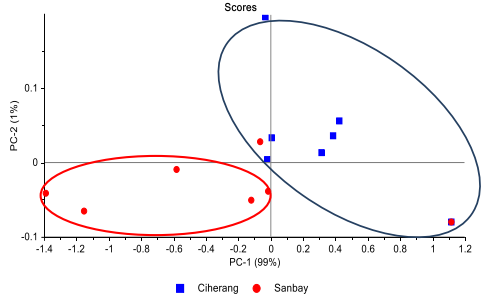

(a)

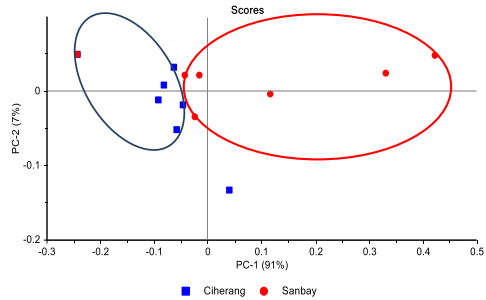

(b)

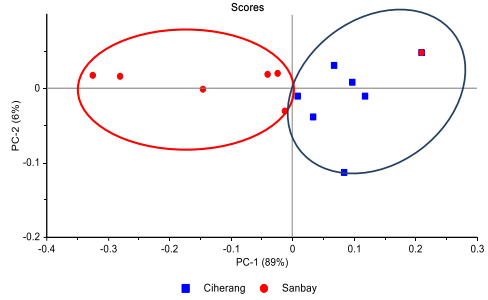

(c)

Gambar 4. Klasifikasi PCA (a) Tanpa Pretreatment (b) Pretreatment MSC dan (c) Pretreatment DT Beras Sanbay dan Ciherang

Klasifikasi beras Sanbay dan beras Sigupai tanpa pretreatment menggunakan metode PCA berhasil dibedakan meskipun terdapat banyak sharing data (50\%) dengan menghasilkan total (PC-1 dan PC-2) adalah sebesar 99. Data ini terklasifikasi cukup baik dengan presentase keberhasilan sebesar 100\%. Klasifikasi beras Aceh (Sanbay) dan beras Nasional (Ciherang) masing-masing terklasifikasi sebesar 100\%. Klasifikasi PCA beras Sanbay dan beras Ciherang tanpa pretreatment dapat dilihat pada Gambar 5 (a).

Selanjutnya klasifikasi beras Sanbay dan beras Sigupai dengan penambahan pretreatment MSC menggunakan metode PCA berhasil dibedakan meskipun terdapat banyak sharing data (50\%) dengan menghasilkan total (PC-1 dan PC-2) adalah sebesar $95 \%$. Data ini terklasifikasi cukup baik dengan presentase keberhasilan sebesar $100 \%$. Klasifikasi beras Aceh (Sanbay) dan beras Nasional (Ciherang) masing-masing terklasifikasi sebesar 100\%. Klasifikasi PCA beras Sanbay dan beras Ciherang tanpa pretreatment dapat dilihat pada Gambar 5 (b).

Klasifikasi beras Sanbay dan beras Sigupai dengan penambahan pretreatment DT menggunakan metode PCA berhasil dibedakan meskipun terdapat banyak sharing data (50\%) dengan menghasilkan total (PC-1 dan PC-2) adalah sebesar 98\%. Data ini terklasifikasi cukup baik dengan presentase keberhasilan sebesar $100 \%$. Klasifikasi beras Aceh (Sanbay) dan beras Nasional (Ciherang) masing-masing terklasifikasi sebesar $100 \%$. Klasifikasi PCA beras Sanbay dan beras Ciherang tanpa pretreatment dapat dilihat pada Gambar 5 (c).

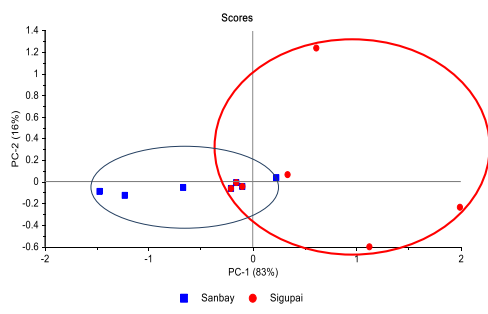

(a)

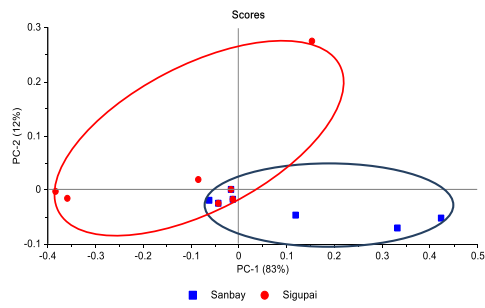

(b)

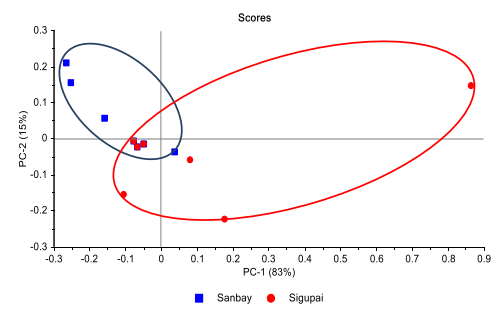

(c)

Gambar 5. Klasifikasi PCA (a) Tanpa Pretreatment (b) Pretreatment MSC dan (c) Pretreatment DT Beras Sanbay dan Sigupai

\section{Klasifikasi Pencampuran Beras Sigupai dengan Beras Ciherang}

Pada tahap ini pencampuran beras Sigupai dan beras Ciherang akan dikelompokkan menjadi empat kelompok data (Gambar 6 a) yaitu beras Sigupai100\%, Sigupai75\%, Sigupai50\% dan Sigupai25\%. Klasifikasi metode PCA tanpa pretreatment pada pencampuran antara beras Aceh (Sigupai) dengan beras Nasional (Ciherang) menghasilkan total (PC-1 dan PC-2) adalah sebesar 99\%. Data ini terklasifikasi secara baik dengan 
presentase keberhasilan sebesar 87,5\%. Yang mana beras Sigupai100\%, Sigupai75\%, Sigupai50\% dan Sigupai25\% masing-masing terklasifikasi sebesar 100\%, 100\%, 62,5\% dan $87,5 \%$. Namun di dalam empat kelompok pencampuran itu banyak terdapat sharing data, sehingga perlu penyederhanaan menjadi dua kelompok data (Gambar 6 b) yaitu Sigupai $\geq$ 75 (Sigupai $100 \%+$ Sigupai $75 \%)$ dan Sigupai $\leq 50$ (Sigupai50\% + Sigupai $25 \%)$.

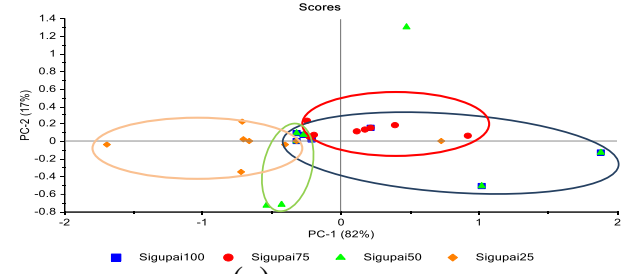

(a)

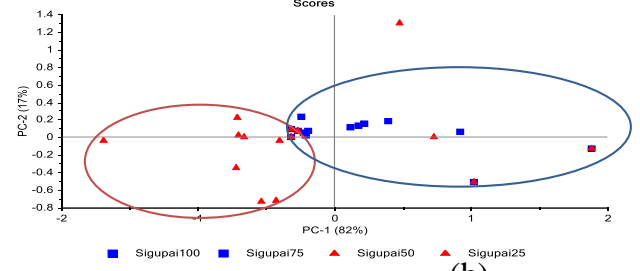

(b)

Gambar 6. Klasifikasi PCA Tanpa Pretreatment Pencampuran (a) Empat Kelompok Data (b) Dua Kelompok Data

Berdasarkan Gambar 6 (b) dapat dilihat setelah dilakukan penyederhanaan, data terklasifikasi secara baik dengan presentase keberhasilan 87,5\%. Yang mana beras Sigupai $\geq 75$ (Sigupai $100 \%+$ Sigupai $75 \%)$ dan Sigupai $\leq 50$ (Sigupai $50 \%+$ Sigupai $25 \%)$ masingmasing terklasifikasi sebesar $100 \%$ dan $75 \%$. Selain itu sharing data antar kelompok juga berkurang menjadi $18,75 \%$.

Hasil klasifikasi PCA terhadap keempat kelompok dengan penambahan pretreatment MSC dapat dilihat pada Gambar 7 (a). Klasifikasi metode PCA menggunakan pretreatment MSC pencampuran antara beras Aceh (Sigupai) dengan beras Nasional (Ciherang) menghasilkan total (PC-1 dan PC-2) adalah sebesar 92\%. Data ini terklasifikasi secara baik dengan presentase keberhasilan sebesar 84,4\%. Yang mana beras Sigupai100\%, Sigupai75\%, Sigupai $50 \%$, Sigupai $25 \%$ masing-masing terklasifikasi sebesar 100\%, 100\%, $62,5 \%$ dan $75 \%$. Namun di dalam setiap pencampuran itu banyak terdapat sharing data kecuali kelompok data Sigupai $25 \%$, sehingga perlu penyederhanaan menjadi hanya dua kelompok data yaitu Sigupai $\geq 75$ (Sigupai $100 \%+$ Sigupai75\%) dan Sigupai $\leq 50$ (Sigupai50\% + Sigupai25\%). Hasil klasifikasi dalam dua kelompok dapat dilihat pada Gambar 7 (b).

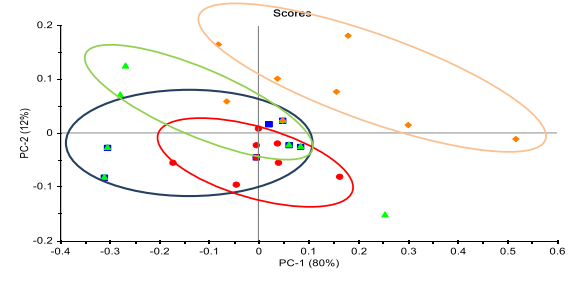

(a)

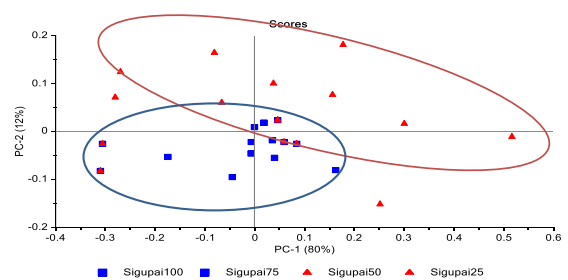

(b)

Gambar 7. Klasifikasi PCA Pretreatment MSC Pencampuran (a) Empat Kelompok Data (b) Dua Kelompok Data

Berdasarkan Gambar 7 (b) dapat dilihat setelah dilakukan penyederhanaan, data terklasifikasi secara baik dengan presentase keberhasilan bertambah menjadi 87,5\%. Yang mana beras Sigupai $\geq 75$ (Sigupai $100 \%+$ Sigupai75\%) dan Sigupai $\leq 50$ (Sigupai $50 \%+$ Sigupai $25 \%$ ) masing-masing terklasifikasi sebesar $100 \%$ dan $75 \%$. Selain itu data sharing diantara kelompok data juga berkurang menjadi hanya sebesar 28,13\%.

Klasifikasi metode PCA dengan penambahan pretreament DT pada pencampuran antara beras Aceh (Sigupai) dengan beras Nasional (Ciherang) menghasilkan total (PC-1 dan PC-2) adalah sebesar 94\%. Data ini terklasifikasi secara baik dengan presentase keberhasilan 
sebesar 84,4\%. Yang mana beras Sigupai $100 \%$, Sigupai75\%, Sigupai50\%, Sigupai $25 \%$ masing-masing terklasifikasi sebesar 100\%, 100\%, 75\% dan 62,5\%. Namun di dalam setiap pencampuran itu banyak terdapat sharing data kecuali kelompok data Sigupai $25 \%$, sehingga perlu penyederhanaan menjadi dua kelompok data yaitu Sigupai $\geq 75$ (Sigupai $100 \%+$ Sigupai $75 \%$ ) dan Sigupai $\leq 50$ (Sigupai $50 \%+$ Sigupai $25 \%$ ).

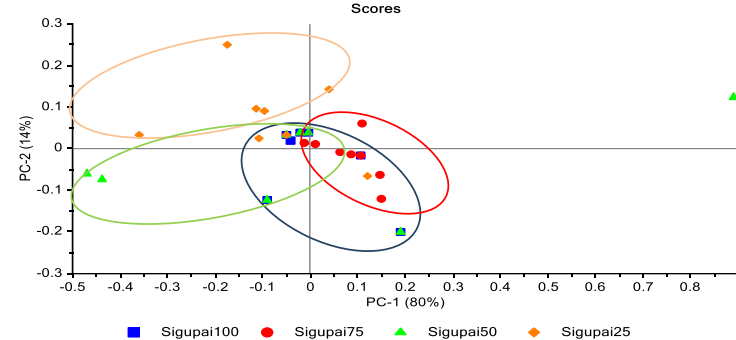

(a)

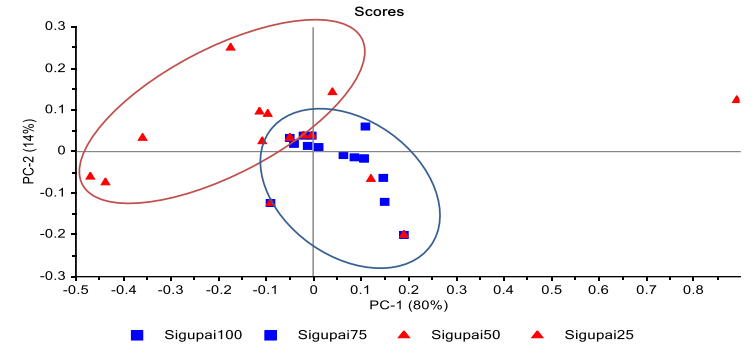

(b)

Gambar 8. Klasifikasi PCA Pretreatment DT Pencampuran (a) Empat Kelompok Data (b) Dua Kelompok Data

Berdasarkan Gambar 8 (b) dapat dilihat setelah dilakukan penyederhanaan, data terklasifikasi secara baik dengan presentase keberhasilan bertambah menjadi 87,5\%. Yang mana beras Sigupai $\geq 75$ Sigupai $100 \%+$ Sigupai $75 \%$ ) dan Sigupai $\leq 50$ (Sigupai $50 \%+$ Sigupai $25 \%$ ) masing-masing terklasifikasi sebesar $100 \%$ dan $75 \%$. Selain itu data sharing diantara kelompok data juga berkurang menjadi hanya sebesar $21,88 \%$.

Berdasarkan model yang dibangun untuk klasifikasi beras berdasarkan varietas menggunakan PCA dapat dikatakan bahwa semua model tersebut cukup baik. Dimana hasil klasifikasi tanpa pretreatment dengan tingkat keberhasilan sebesar 86,9\%, klasifikasi penambahan pretreatment MSC dengan tingkat keberhasilan sebesar 85,5\% dan klasifikasi penambahan pretreatment DT dengan tingkat keberhasilan sebesar $87 \%$. Sehingga dapat disimpulkan bahwa klasifikasi menggunakan pretreatment DT merupakan salah satu klasifikasi paling baik dibandingkan tanpa pretreatment dan menggunakan pretreatment MSC.

\section{SIMPULAN DAN SARAN}

\section{Simpulan}

Berdasarkan hasil penelitian yang telah dilakukan maka yang dapat disimpulkan sebagai berikut:

1. Spektrum NIRS beras menunjukkan keberadaan kandungan lemak pada panjang gelombang $2355 \mathrm{~nm}-2462 \mathrm{~nm}$. Kandungan karbohidrat pada panjang gelombang 2256 $\mathrm{nm}-2321 \mathrm{~nm}$. Kandungan protein pada panjang gelombang $2056 \mathrm{~nm}-2166 \mathrm{~nm}$. Kandungan kadar air pada panjang gelombang $1910 \mathrm{~nm}-1980 \mathrm{~nm}$ dan panjag gelombang 1411 nm - 1492 nm menunjukkan kandungan protein dan kadar air.

2. NIRS dengan metode PCA mampu membedakan pencampuran beras Sigupai dengan beras Ciherang dimana pembedaan terbaik terjadi dalam bentuk dua macam pengelompokan yaitu beras Sigupai $\geq 75$ dan beras Sigupai $\leq 50$.

3. Pretreatment de-trending merupakan pretreatment terbaik dalam mengklasifikasi beras Aceh (Sigupai dan Sanbay) dengan beras Nasional (Ciherang). 


\section{Saran}

Berdasarkan hasil penelitian yang telah dilakukan, saran yang dapat dikemukakan untuk penelitian selanjutnya adalah dapat dilakukan klasifikasi pada sampel beras Aceh lainnya berdasarkan daerah-daerah asalnya dan juga perlu dilakukan penelitian lebih lanjut dengan menggunakan metode klasifikasi yang lebih spesifik.

\section{DAFTAR PUSTAKA}

Cen, H dan Y. He. 2007. Theory and application of near infrared reflectance spectroscopy in determination of food quality. J. Trends in Food Sci \& Technol.18:72-83.

Chen, J.Y. Yelian, M. Satoshi, S dan Han, Z. 2008. Near Infrared Spectroscopy for Determination of the Protein Composition of Rice Flour. Food Sci. Technol. Res., $14(2), 132-138$.

Bakhtiar, E. 2009. Pengembangan Padi yang Berbasis Potensi Lokal Aceh. Univarsity Farm Universitas Syiah Kuala Sub Stasion Pengembangan Padi.

Firdaus, J., R. Hasbullah, U. Ahmad dan M. R. Suhartanto. 2014. Deteksi Cepat Viabilitas Benih Padi Menggunakan Gelombang Near Infrared dan Model Jaringan Saraf Tiruan. Jurnal Penelitian Tanaman Pangan. Vol. 33 (22). 77-86.

Klaithin, R. Thawatchai, P. Parichat, T. Kaewalin, K. Sa-nguansak, T dan Suchada V. 2012. Pasting Cell: An Alternative Sample Cell for Detection of Aspergillus flavus Infected Milled Rice by NIR Spectroscopy. CMU.J.Nat.Sci.Special Issue on Agricultural \& Natural Resources Vol. 11 (1).

Munawar, A, A. 2014. Multivariate Analysis and Artificial Neural Network Approaches of Near Infrared Spectroscopy Data for Non-Destructive Quality Attributes Prediction of Mango. Goettingen. George-August University.

Osborne, B. G., Fean, T., Hindle, P. H. 1993. Practical NIR Spectroscopy. Longman Scientific and Technical, United Kingdom.

Zulfahrizal, A. A. Munawar dan H. Meilina. 2016. Estimasi Kandungan Lemak Pada Biji Kakao Utuh Secara Cepat dan Non-Destrukktif dengan Menggunakan Teknologi NIRS. Jurnal Otomasi, Kontrol dan Instrumentasi. Vol. 8 (1). 17-24.

Zulfahrizal, A.A. Munawar, dan H. Meilina. 2017. Rancang Bangun Alat Sensor Portable Berbasis Pengembangan Aplikasi Teknologi Near Infrared Sebagai Metode Baru yang Rapid dan Non-Destructive untuk prediksi Kualitas Kakao. Prosiding Seminar Nasional Pasca Sarjana Universias Syiah Kuala. 32-37. 